\begin{tabular}{|c|c|c|c|}
\hline \multirow{2}{*}{$\begin{array}{r}\text { Case Reports in } \\
\text { Gastroenterology }\end{array}$} & \multicolumn{2}{|c|}{ Case Rep Gastroenterol 2018;12:13-18 } & \multirow[b]{2}{*}{$\begin{array}{l}\text { Karger } \\
\text { Open access }\end{array}$} \\
\hline & $\begin{array}{l}\text { DOI: } 10.1159 / 000486189 \\
\text { Published online: January 17, } 2018\end{array}$ & $\begin{array}{l}\text { (c) } 2018 \text { The Author(s) } \\
\text { Published by S. Karger AG, Basel } \\
\text { www.karger.com/crg }\end{array}$ & \\
\hline & $\begin{array}{l}\text { This article is licensed under the } \\
\text { International License (CC BY-NC) } \\
\text { Usage and distribution for commerc }\end{array}$ & $\begin{array}{l}\text { nons Attribution-NonCommercial } 4 . \\
\text { ger.com/Services/OpenAccessLicense) } \\
\text { uires written permission. }\end{array}$ & \\
\hline
\end{tabular}

\title{
Severe Hepatic and Pulmonary Involvement in Rendu-Osler-Weber Syndrome
}

\author{
Xavier Verhelst $^{a} \quad$ Anja Geerts $^{a} \quad$ Hans Van Vlierberghe $^{a} \quad$ Peter Smeets $^{b}$ \\ Clarisse Lecluyse ${ }^{b}$ \\ ${ }^{a}$ Department of Hepatology and Gastroenterology, Ghent University Hospital, \\ Ghent, Belgium; 'bepartment of Radiology, Ghent University Hospital, Ghent, Belgium
}

\section{Keywords}

Hepatic involvement · Pulmonary involvement $\cdot$ Rendu-Osler-Weber syndrome

\begin{abstract}
We report the case of a young woman with hereditary hemorrhagic telangiectasia (HHT) with severe liver involvement and pulmonary shunting. The medical imaging in this patient illustrates the severe shunting that can occur in these patients who often are asymptomatic. By showing this case, we want to highlight the role of liver transplantation in HHT with hepatic involvement.

\section{Introduction}

Hereditary hemorrhagic telangiectasia (HHT) is an inherited vascular disorder affecting 1 in 5,000-8,000 people [1]. The disease is inherited as an autosomal dominant trait. HHT gene mutations are located in genes encoding proteins involved in the transforming growth factor (TGF)- $\beta$ superfamily signaling in vascular endothelial cells, leading to the development of abnormal vascular structures [2]. Clinical HHT presentation patterns vary widely among and within families, ranging from dilated microvessels to large arteriovenous malformations (AVMs). These abnormalities can lead to anemia, recurrent epistaxis, and gastrointestinal blood loss $[3,4]$. These patients develop AVMs of the pulmonary, hepatic, and cer- 
ebral circulation [2]. AVMs affect the majority of patients but often remain silent [5]. In a minority of patients, major complications can develop over time and include severe anemia from chronic nasal and gastrointestinal blood loss, stroke, deep venous thromboembolism, symptomatic liver disease, and severe pulmonary hypertension [6, 7].

The genetic basis of the disease includes 3 genotypes. HHT type 1 results from mutations in ENG encoding endoglin (chromosome 9) [8], HHT type 2 is the result of mutations in ACVRL1 encoding ALK1 (chromosome 12) [9], and HHT in association with juvenile polyposis results from mutations in MADH4 (chromosome 18) [10]. Two other unidentified genes have been related to HHT development, HHT3 and HHT4 $[11,12]$.

The clinical diagnosis of HHT is based on the presence of at least 3 of the "Curaçao criteria," including spontaneous recurrent nosebleeds, mucocutaneous telangiectasia, visceral involvement, or a first-degree family history of HHT [3]. After the diagnosis of HHT, clinical workup should include a detailed family history, referring the patient with particular problems to an organ-specific specialist with experience in HHT, screening for asymptomatic AVMs, formalizing the diagnosis of HHT, which may include molecular testing, and providing information and opportunity for follow-up and family screening [2].

\section{Case Report}

This 36-year-old woman who suffered from recurrent epistaxis since her childhood was referred due to elevated liver enzymes (bilirubin $1.8 \mathrm{mg} / \mathrm{dL}$, AST $143 \mathrm{U} / \mathrm{L}$, ALT $90 \mathrm{U} / \mathrm{L}$, GGT $1,060 \mathrm{U} / \mathrm{L}$, and AF $366 \mathrm{U} / \mathrm{L}$ ). She reported no specific complaints. At clinical examination, a vascular sound could be heard in the epigastric region at auscultation. Abdominal ultrasonography with duplex showed multiple large vascular structures in the liver. The importance of these vascular malformations was confirmed using a CT scan. A coronal maximum intensity projection image (arterial phase; Fig. 1) showed large, tortuous extrahepatic and intrahepatic arteries (black arrows) and diffuse punctate telangiectasias in the liver parenchyma (white arrowheads). Also, 2 pulmonary AVMs were noted in the left upper and right lower lobe (white arrows). Three-dimensional volume-rendered arterial phase image (Fig. 2) showed early opacification of the hepatic veins (white arrows) secondary to arteriovenous shunting, also illustrated by the axial arterial (Fig. 3a) and hepatic (Fig. 3b) phase images. Note the numerous telangiectasias (arrowheads and brace).

The clinical suspicion of a Rendu-Osler-Weber syndrome was confirmed by genetic analysis which confirmed a c.430C $>$ T (p.arg144*) mutation in the ALK1 gene. Echocardiography revealed a mild pulmonary hypertension (gradient $45-55 \mathrm{~mm} \mathrm{Hg}$, central venous pressure 10-15 $\mathrm{mm} \mathrm{Hg}$ ) with a mild concentric remodeling of the right ventricular wall. Due to the pulmonary hypertension, the patient will be considered for liver transplantation.

\section{Discussion}

HHT or Rendu-Osler-Weber disease is an autosomal dominant dysplasia characterized by widespread cutaneous, mucosal, and visceral telangiectasias $[3,13]$. These telangiectasias, the hallmark of the disease, arise from the dilatation of postcapillary venules which directly fuse with an arteriole, thus bypassing the capillary system [14]. The clinical presentation can vary from mild to very extensive. Complications occur when visceral organs are affected, such as the brain, the lungs, and the liver [15]. 
Liver involvement can be discrete and limited to vascular derangements on a microscopical level and can range to large direct shunts between the hepatic arteriolar branches and sinusoids (leading to arteriovenous shunts), between the portal vein and the central veins (portovenous shunts), and between the hepatic artery and the portal vein [14]. Our patient suffered from the first scenario. These hepatic malformations can lead to liver enlargement and (peri)portal fibrosis and a noncirrhotic nodular transformation of the liver [16]. An increased number of focal nodular hyperplasias have been witnessed in these patients [17].

Patients with HHT are generally asymptomatic [18]. The main risk of large arteriovenous shunting is the development of high-output congestive heart failure [14, 15, 19]. Thus, once diagnosis of hepatic involvement in HHT is established, periodical echocardiography is advised [14]. In the presence of arterioportal shunts, portal hypertension can develop, and upper gastrointestinal endoscopy should be performed in order to detect esophageal varices [14]. Some patients will develop an anicteric cholestasis, which can lead to severe cholestasis and sepsis in rare cases [14].

Liver transplantation can be the only definitive curative option for patients with HHT with advanced hepatic involvement [19]. The main indications for liver transplantation are high-output cardiac failure, severe portal hypertension, and extended biliary necrosis [19]. Outcome after liver transplantation is excellent, with a 10-year patient and graft survival rate of 83\% [19]. Recurrence of the disease after liver transplantation has been reported in 2 patients [20].

\section{Statement of Ethics}

Informed consent was obtained from the patient for publication of her information.

\section{Disclosure Statement}

The authors have nothing to disclose.

\section{References}

1 Bideau A, Brunet G, Heyer E, Plauchu H, Robert JM: An abnormal concentration of cases of Rendu-Osler disease in the Valserine valley of the French Jura: a genealogical and demographic study. Ann Hum Biol 1992;19:233-247.

-2 Govani FS, Shovlin CL: Hereditary haemorrhagic telangiectasia: a clinical and scientific review. Eur J Hum Genet 2009;17:860-871.

-3 Shovlin CL, Guttmacher AE, Buscarini E, et al: Diagnostic criteria for hereditary hemorrhagic telangiectasia (Rendu-Osler-Weber syndrome). Am J Med Genet 2000;91:66-67.

4 Rendu H: Epistaxis répétées chez un sujet porteur de petitis angiomes cutanés et muquez. Gaz des Hop 1896;135:1322-1323.

-5 Guttmacher AE, Marchuk DA, White RI: Hereditary hemorrhagic telangiectasia. N Engl J Med 1995;333:918-924.

-6 Smith JL, Lineback MI: Hereditary hemorrhagic telangiectasia; nine cases in one Negro family, with special reference to hepatic lesions. Am J Med 1954;17:41-49.

-7 Román G, Fisher M, Perl DP, Poser CM: Neurological manifestations of hereditary hemorrhagic telangiectasia (Rendu-Osler-Weber disease): report of 2 cases and review of the literature. Ann Neurol 1978;4:130-144.

8 McAllister KA, Grogg KM, Johnson DW, et al: Endoglin, a TGF-beta binding protein of endothelial cells, is the gene for hereditary haemorrhagic telangiectasia type 1. Nat Genet 1994;8:345-351. 
Verhelst et al.: Severe Hepatic and Pulmonary Involvement in Rendu-Osler-Weber Syndrome

$\longrightarrow 9$ Johnson DW, Berg JN, Baldwin MA, et al: Mutations in the activin receptor-like kinase 1 gene in hereditary haemorrhagic telangiectasia type 2. Nat Genet 1996;13:189-195.

10 Gallione CJ, Repetto GM, Legius E, et al: A combined syndrome of juvenile polyposis and hereditary haemorrhagic telangiectasia associated with mutations in MADH4 (SMAD4). Lancet 2004;363:852859.

11 Cole SG, Begbie ME, Wallace GMF, Shovlin CL: A new locus for hereditary haemorrhagic telangiectasia (HHT3) maps to chromosome 5. J Med Genet 2005;42:577-582.

12 Bayrak-Toydemir P, McDonald J, Akarsu N, et al: A fourth locus for hereditary hemorrhagic telangiectasia maps to chromosome 7. Am J Med Genet A 2006;140:2155-2162.

13 Fuchizaki U, Miyamori H, Kitagawa S, Kaneko S, Kobayashi K: Hereditary haemorrhagic telangiectasia (Rendu-Osler-Weber disease). Lancet 2003;362:1490-1494.

14 Buscarini E, Danesino C, Olivieri C, Lupinacci G, Zambelli A: Liver involvement in hereditary haemorrhagic telangiectasia or Rendu-Osler-Weber disease. Dig Liver Dis 2005;37:635-645.

15 Garcia-Tsao G, Korzenik JR, Young L, et al: Liver disease in patients with hereditary hemorrhagic telangiectasia. N Engl J Med 2000;343:931-936.

16 Wanless IR, Gryfe A: Nodular transformation of the liver in hereditary hemorrhagic telangiectasia. Arch Pathol Lab Med 1986;110:331-335.

17 Buscarini E, Danesino C, Plauchu H, et al: High prevalence of hepatic focal nodular hyperplasia in subjects with hereditary hemorrhagic telangiectasia. Ultrasound Med Biol 2004;30:1089-1097.

18 Memeo M, Stabile Ianora AA, Scardapane A, et al: Hereditary haemorrhagic telangiectasia: study of hepatic vascular alterations with multi-detector row helical CT and reconstruction programs. Radiol Med 2005;109:125-138.

19 Lerut J, Orlando G, Adam R, et al: Liver transplantation for hereditary hemorrhagic telangiectasia. Ann Surg 2006;244:854-864.

20 Sabbà C, Gallitelli M, Longo A, Cariati M, Angelelli G: Orthotopic liver transplantation and hereditary hemorrhagic telangiectasia: do hepatic vascular malformations relapse? A long term follow up study on two patients. J Hepatol 2004;41:687-689. 


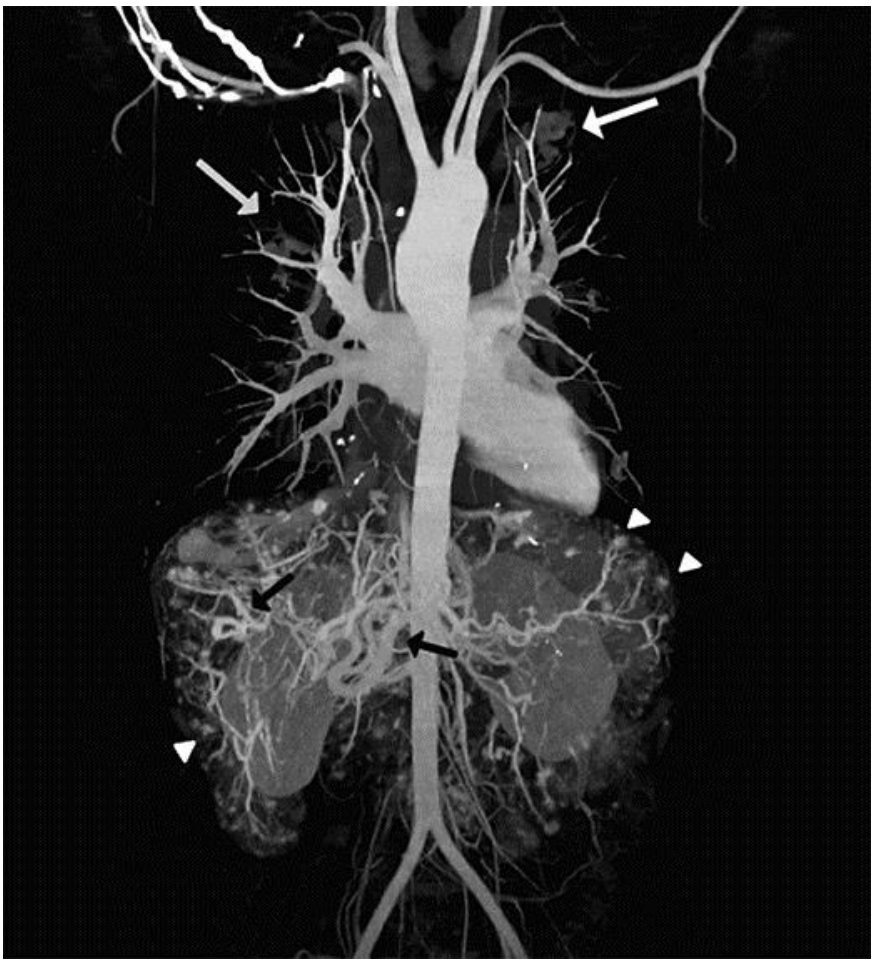

Fig. 1. Coronal maximum intensity projection image obtained in the arterial phase shows large, tortuous extrahepatic and intrahepatic arteries (black arrows) and diffuse punctate telangiectasias in the liver parenchyma (white arrowheads). Also note 2 pulmonary arteriovenous malformations in the left upper and right lower lobe (white arrows).

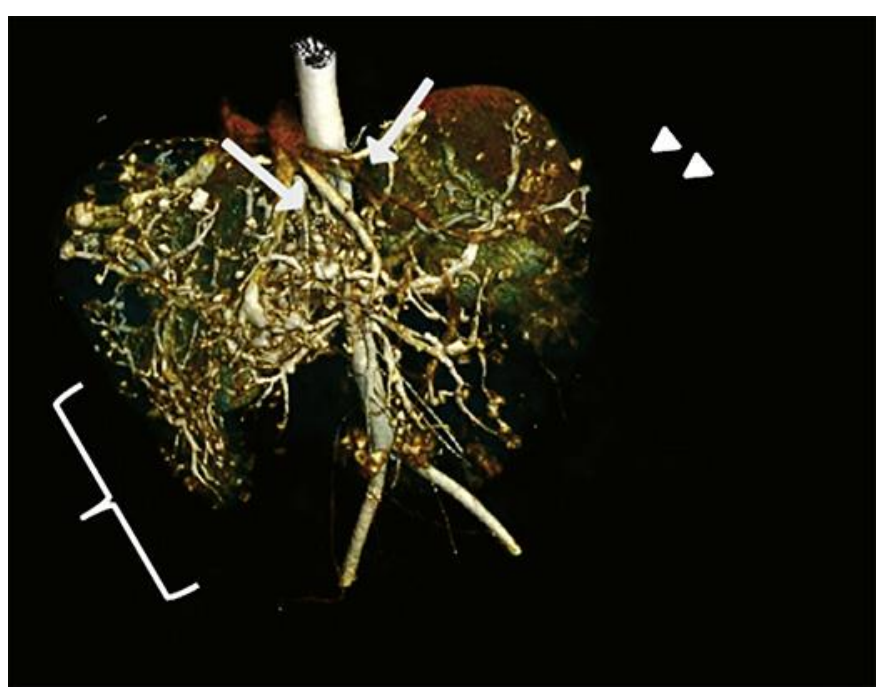

Fig. 2. Hepatic lesions in a 36-year-old woman with hereditary hemorrhagic telangiectasia. Threedimensional volume-rendered arterial phase image shows early opacification of the hepatic veins (white arrows) secondary to arteriovenous shunting. Note the numerous telangiectasias (arrowheads and brace). 


\section{Case Reports in Gastroenterology

\begin{tabular}{l|l}
\hline Case Rep Gastroenterol 2018:12:13-18 \\
\hline DOI: 10.1159/000486189 & $\begin{array}{l}\text { C 2018 The Author(s). Published by S. Karger AG, Basel } \\
\text { www.karger.com/crg }\end{array}$ \\
\hline
\end{tabular} \\ Verhelst et al.: Severe Hepatic and Pulmonary Involvement in Rendu-Osler-Weber Syndrome}
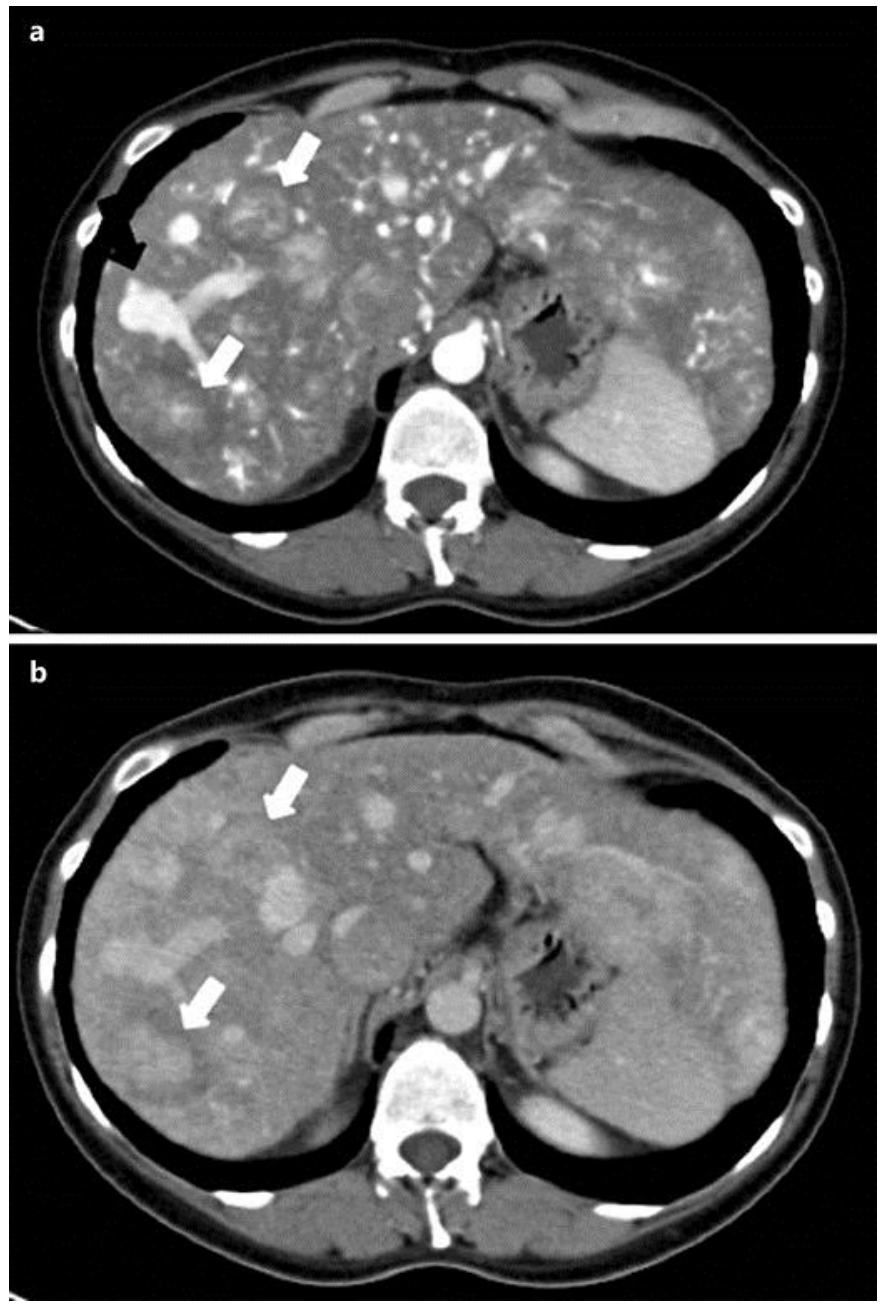

Fig. 3. Axial arterial (a) and hepatic (b) phase images show a large arteriovenous shunt in the right lobe (black arrow) and multiple focal nodular hyperplasias (white arrows). 